\title{
Barcodes of marine invertebrates from north Iberian ports: Native diversity and resistance to biological invasions
}

\author{
L. Miralles a , A. Ardura ${ }^{\text {b }}$, A. Arias ${ }^{\text {c }}$, Y.J. Borrell a , L. Clusa ${ }^{\text {a }}$, E. Dopico ${ }^{\text {d }}$, A. Hernandez de Rojas ${ }^{\text {e }}$, B. Lopez ${ }^{\text {, }}$, \\ M. Muñoz-Colmenero ${ }^{a}$, A. Roca ${ }^{a}$, A.G. Valiente ${ }^{a}$, A. Zaiko ${ }^{\text {, }}$ E. Garcia-Vazquez ${ }^{\mathrm{a}, *}$ \\ a Department of Functional Biology, University of Oviedo, 33071 Oviedo, Spain \\ b Laboratoire d'Excellence "CORAIL", Université de Perpignan CBETM, 58 rue Paul Alduy, 66860 Perpignan Cedex, France \\ c Department of Biology of Organisms and Systems, University of Oviedo, 33071 Oviedo, Spain \\ d Department of Education Sciences, University of Oviedo, 33071 Oviedo, Spain \\ e Oceanographic Institute of Spain, Avda. Príncipe de Asturias, 70 bis, 33212 Gijon, Spain \\ ${ }^{\mathrm{f}}$ Coastal and Freshwater Group, Cawthron Institute, 98 Halifax Street East, 7010 Nelson, New Zealand
}

\section{A R T I C L E I N F O}

\section{Article history:}

Received 14 July 2016

Received in revised form 6 August 2016

Accepted 8 August 2016

Available online 12 August 2016

\section{Keywords:}

Non-indigenous species

Biotic resistance

Marine biological invasions

DNA barcoding

Ports

\begin{abstract}
A B S T R A C T
Ports are gateways for many marine organisms transported by ships worldwide, especially non-indigenous species (NIS). In this study carried out in North Iberian ports (Cantabrian Sea, Bay of Biscay) we have observed 38\% of exotic macroinvertebrates. Four species, namely the barnacle Austrominius modestus, the tubeworm Ficopomatus enigmaticus, the Pacific oyster Crassostrea gigas and the pygmy mussel Xenostrobus securis, exhibited clear signs of invasiveness. A total of 671 barcode (cytochrome oxidase subunit I or 18S rRNA) genes were obtained and confirmed the species status of some cryptic NIS. Negative and significant correlation between diversity estimators of native biota and proportion of NIS suggests biotic resistance in ports. This could be applied to management of port biota for contributing to prevent the settlement of biopollutants in these areas which are very sensitive to biological invasions.
\end{abstract}

(c) 2016 Elsevier Ltd. All rights reserved.

\section{Introduction}

Biological pollution is a main challenge in marine settings (Molnar et al., 2008). In marine biological invasions, as in other fields related to environmental risks and biosecurity, there is a general consensus: prevention is more efficient than treatment. Once established in a new location, eradicating invasive populations is extremely challenging, costly and in many cases not feasible (Bax et al., 2003; Thresher and Kuris, 2004; Williams and Schroeder, 2004). Actions for controlling biological invasions are the most efficient at the early stage of incursion (Myers et al., 2000; Hopkins et al., 2011; Miralles et al., 2016). Thus early detection of invasive species is a crucial step for successful post-introduction management (e.g. Pochon et al., 2015; Devloo-Delva et al., 2016). For the successful prevention of new invasions it is especially important to identify the main features of recipient communities that may make them resistant to invasions. Both habitat conditions and biological properties of the recipient ecosystem determine the success of aquatic invasions (e.g. Zaiko et al., 2007, 2011; Valiente et al., 2010a, 2010b), being generally facilitated in degraded environments (e.g. MacDougall and Turkington, 2005; Linde et al., 2008).

\footnotetext{
* Corresponding author.

E-mail address: egv@uniovi.es (E. Garcia-Vazquez).
}

One of the factors that may confer resistance to invasions is native biodiversity of the recipient community, a phenomenon called biotic resistance. More diverse communities are expected to be more resistant to invasions than empoverished communities (e.g. Stachowicz et al., 1999; Byers and Noonburg, 2003). This fact has been explained from the presence of fewer niches available for invaders in rich communities (Stachowicz et al., 1999), although the effect is not clear and there are discrepancies between studies (Fridley et al., 2007).

Ports are gates for marine invasions (Molnar et al., 2008; Ardura et al., 2015; Pejovic et al., 2016). Their generally degraded environment adds to the constant entrance of biota carried by ships (e.g. Seebens et al., 2013). If biotic resistance occurs also in degraded ecosystems, for similar environment and number of ship arrivals, ports with rich local communities should be less prone to biological invasions than ports with fewer native species. Here we tested this hypothesis in the central part of the Iberian Bay of Biscay, coast of Asturias region in Northern Spain. We have inventoried fouling animal communities from ports of different size, quantified native biodiversity and determined its correlation with the abundance of non-native species. Samples of fouling communities attached to artificial port structures were sampled from eight ports. DNA barcoding was carried out for accurate species identification, including cryptic species, and biodiversity estimated. 


\section{Material and methods}

\subsection{Study region}

The considered ports are located in the region of Asturias $\left(43^{\circ} 20^{\prime} \mathrm{N}\right.$ $6^{\circ} 00^{\prime} \mathrm{W}$ ) in the Cantabrian Sea coast (Bay of Biscay) in the northern Iberian Peninsula. Eight ports were studied, from West to East: Figueras, Luarca, Cudillero, Aviles, Gijon, Villaviciosa, Ribadesella and Llanes (Fig. 1). Aviles and Gijon are commercial ports under national Spanish authority that receive large international cargo vessels, and also have adjacent fishing ports and marinas. The other six locations are fishing ports and associated marinas under Asturias regional authority, serving for local maritime traffic, arrival of fishing catch (from national and international waters) and recreational boating.

In this specific region introduction of exotics from shellfish aquaculture (Pacific oyster Crassostrea gigas, Japanese carpet shell Ruditapes philippinarum, hard clam Mercenaria mercenaria) has been reported previously (e.g. Arias and Anadón, 2012; Habtemariam et al., 2015; Semeraro et al., 2015). Currently aquaculture production is scarce and is majorly represented by Pacific oyster farms located exclusively in the Eo estuary near Figueras port (Semeraro et al., 2015). Pacific oysters were also grown in Ribadesella in the past and are still present in the wild (Fabioux et al., 2002). Other marginal shellfish production is carpet shell and razor clam that are harvested in Villaviciosa (artisanal harvesting). They are supported with stocking practices. In the rest of the region there is no marine aquaculture, so it does not contribute much as a potential pathway for NIS introductions.

\subsection{Sampling methodology}

Sampling protocol followed Pejovic et al. (2016), was inspired by the Rapid Assessment Survey (RAS) approach (Minchin, 2007) and adapted for assemblages living on artificial port structures. For this study, eight ports were selected across Asturias coastline, in the northern Iberian Peninsula (Fig. 1). Three sites were sampled inside each port: one near the port mouth, one in the inner section, one half way between these two. The sites were similarly uncovered by algae and sheltered (inside the port) to avoid environmental sampling biases. To standardize the sampling effort, the surface sampled from each site within each port was approximately $200 \mathrm{~m}^{2}$. Roughly $1 \%$ of the animals visually detected attached on that surface were collected at random. For a representative sampling, and preventing biased collection of species with patchy distribution, a visual inspection prior to sampling was made to determine the phenotypically different organisms (presumably different species) present in the sampling site. The number of individuals picked of each morphotype was approximately proportional to the abundance of such morphotype. All individuals were instantly transported in ambient water (contained in $10 \mathrm{~L}$ buckets) to the Genetic Laboratory of Natural Resources (University of Oviedo) for visual species identification and follow-up molecular analyses. In the laboratory, individuals were

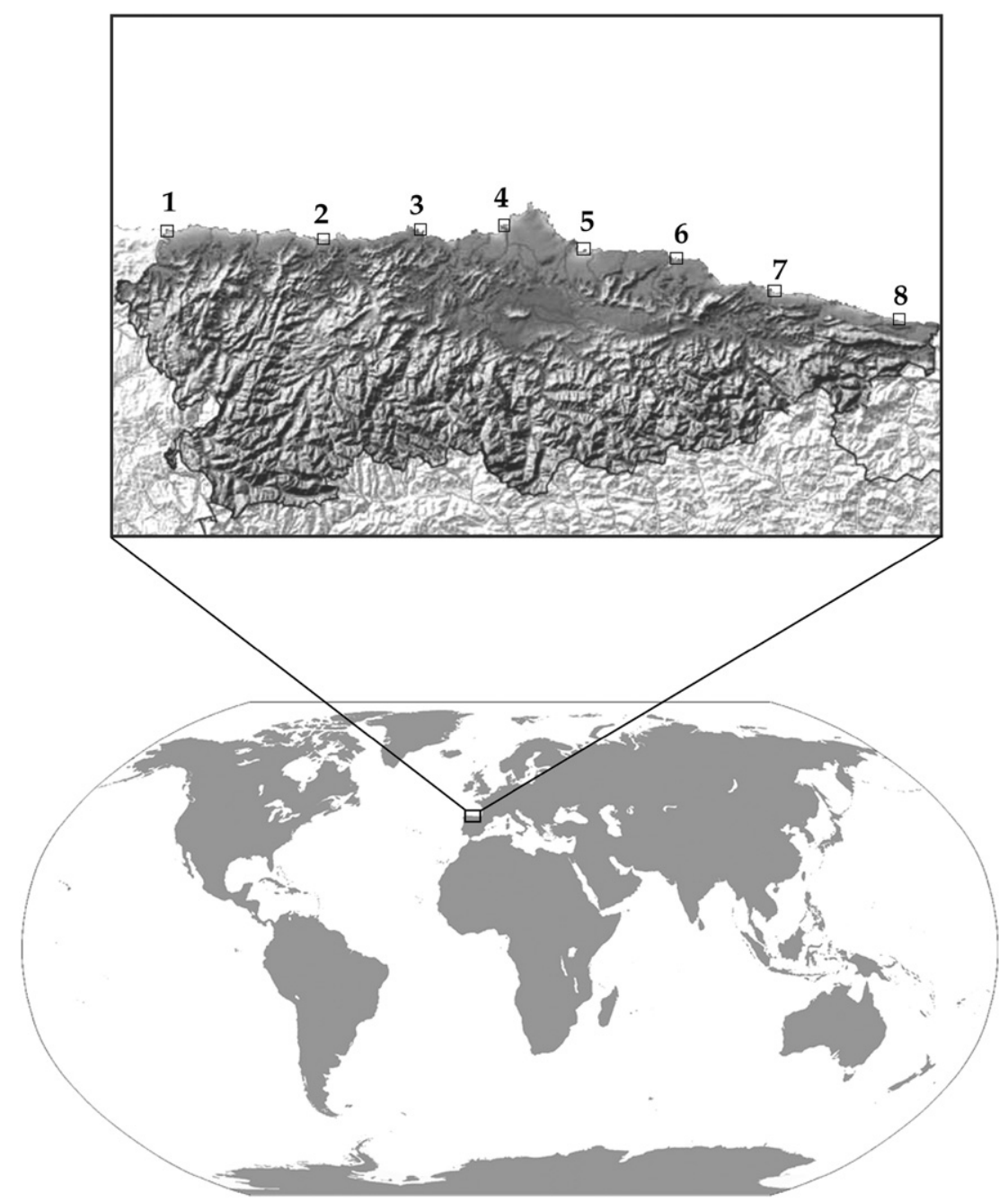

Fig. 1. Map of the Asturias coast showing the ports considered: from 1 to 8 are Figueras, Luarca, Cudillero, Aviles, Gijon, Villaviciosa, Ribadesella and Luarca. 
identified, based on morphology, to the species or to the lowest possible taxonomic level. Then, a piece of tissue from each individual was preserved in absolute ethanol for further genetic analysis. One voucher specimen of each species was stored in ethanol in the Laboratory of Natural Resources of the University of Oviedo.

The Invasive Species Specialist Group (ISSG) global database (http:// www.issg.org/database/welcome/) of the International Union for Conservation of Nature (IUCN) and AquaNIS database (www.corpi.ku.lt/ aquanis) were the references to check the invasiveness status and invasion histories of each identified non-indigenous species. The taxonomic nomenclature of all identified species was verified against the World Register of Marine Species (2016).

\subsection{Genetic barcoding for species confirmation}

DNA was extracted from approximately $10 \mathrm{mg}$ of tissue from the ethanol-preserved individuals using a Chelex® resin (Bio-Rad Laboratories Inc., USA) protocol (Estoup et al., 1996) or the EZNA Mollusc DNA Kit (Omega Bio-Tek Inc., USA).

The mitochondrial cytochrome c oxidase subunit I (COI) gene was amplified using the universal primers designed by Geller et al. (2013) and the conditions described therein. Bovine serum albumin (BSA) was included in the PCR protocol to avoid interferences of possible inhibitors. The nuclear subunit 18S rRNA gene was PCR amplified from species with scarce COI gene references in publically available databases (Bold Systems, NCBI), using the primers and protocol described in Distel et al. (2011). PCR products were examined on $2 \%$ agarose gel stained with SimplySafe ${ }^{\mathrm{TM}}$ (EURx, Poland). Positive amplicons (evidenced by clear single band of the right size) were sequenced in Macrogen Inc. (The Netherlands) with ABI3730xl DNA sequencer (Applied Biosystems).

Obtained DNA sequences were visually inspected and edited with BioEdit v7.2.5 (Hall, 1999). All sequences were compared with online public databases using nBLAST in NCBI (www.ncbi.nlm.nih.gov/) and Bold Systems (www.boldsystems.org/). The sequence giving the maximum score with at least $97 \%$ nucleotide identity and E-value $<\mathrm{e}-100$, was considered the reference for genetic species identification. When no genetic identification was possible with the COI gene due to absence of references in the databases, the reference for 18S rRNA gene was considered.

For species with morphological resemblance with other species, or NIS recently discovered in the region, the species status was validated from phylogenetic analysis. Sequences were aligned with ClustalW (Thompson et al., 1994) application on BioEdit and haplotypes were determined with DnaSP software v5.10 (Librado and Rozas, 2009). A phylogenetic tree was constructed with MEGA v6 (Tamura et al., 2013) using the obtained COI haplotypes and reference sequences from voucher specimens (of known geographical origin) downloaded from NCBI. The method of Maximum Likelihood was employed with the following settings: Tamura Nei model (Tamura and Nei, 1993) and 1000 bootstrap replicates.

\subsection{Biodiversity estimates and statistical analysis}

Diversity of fouling macrofauna assemblages among samples was compared using non-metric multidimensional scaling (nMDS) based on Bray-Curtis similarity matrix of species counts standardized by total percentage abundance of species in a sample. The analysis was undertaken with 100 random restarts and results were visualized in twodimensional nMDS plot. The three samples obtained from each port, each one from $200 \mathrm{~m}^{2}$ surface of artificial structures, were pooled when their diversity was not significantly different. Similarity percentages analysis (SIMPER; Clarke, 1993) was used to identify contribution of individual taxa to differences between macrofauna assemblages in regional and international ports. A non-parametric Chi-square test of independence was employed to test if there is an association between port category (regional or international) and proportion of encountered NIS in the samples. The analyses and calculations were performed in PRIMER 7 (PRIMER-E, Ltd, UK) and R (2014) softwares.

Further analysis was performed excluding NIS and cryptogenic species from samples for determining the diversity of the native community only (Shannon's and Simpson's indices; number of native taxa). Correlations between native diversity and proportion of NIS individuals in a sample were measured with Pearson $r$-values and their significance (based on $r^{2}$ and 6 d.f. for 8 ports) set at $P<0.016$ level from Bonferroni correction for multiple comparisons.

\section{Results}

\subsection{Species detected and barcoded}

In total 671 macrofauna specimens sampled from port locations were identified de visu and sequenced. Barcodes (COI or 18S rRNA gene) were obtained from all of them and allowed to unambiguously identify 78 invertebrate taxa, 70 of them to species level (Supplementary Table 1 ). The DNA Barcodes are available in NCBI database with the accession numbers KU695268-KU695305, KU697654-KU697793, KU714729-KU714835. The 18S rRNA gene sequences of the species Amathia imbricata (Ai), Ficopomatus enigmaticus (Fe), Platynereis dumerilii (Pd), Polydora triglanda (Pt), Spirobranchus triqueter (St), Terebella lapidaria $(\mathrm{Tl})$ and Vermiliopsis striaticeps (Vs) have the references KU559925-KU559931. For these species COI gene references were not available in public databases in the moment of this study (February 2016). DNA analysis confirmed the morphological identification provided by taxonomy expert except for the case of some mussels that were identified de visu as the native species Mytilus galloprovincialis but provided sequences identical to Mytilus edulis (native) or M. trossulus (NIS) references (Supplementary Table 1). Few DNA sequences obtained from individuals morphologically identified to species level did not provide $>97 \%$ identity with any reference species, thus genetic determination was at the genus level (Anemonia sp., Hymeniacidon sp., Littorina sp., Mytilus sp., Ophyotris sp., Syllis sp.), and in one case it was $<93 \%$ and was assigned to a family level (Hyalidae). On the other hand, in some cases DNA sequences allowed identifying phenotypically plastic species (see below).

Overall 20 species were identified as non-indigenous or cryptogenic (Table 1) and comprised $38 \%$ of the 671 individuals barcoded. Nine of these NIS were firstly reported in the Iberian coast in 2014 (this study; Arias et al., 2012; AquaNIS, 2015, database accessed in August 2016; Pejovic et al., 2016). Ten widely distributed NIS with previously reported effects on ecosystem values and services were detected: Amathia verticillata, Austrominius modestus, Bugula neritina, Crassostrea gigas, Crepidula fornicata, Ficopomatus enigmaticus, Styela clava, Styela plicata, Watersipora subtorquata and Xenostrobus securis.

The bryozoan Watersipora subtorquata is a cryptic species difficult to identify de visu (Mackie et al., 2012), and the same happens with other species with phenotypic plasticity like some Bivalvia (Pejovic et al., 2016). In our results six species revealed phenotypic plasticity: Amathia verticillata, Austrominius modestus, Mytilaster minimus, Mytilus trossulus, Watersipora subtorquata and Xenostrobus securis. A Maximum Likelihood tree was constructed to confirm genetic identification of these specific species. The genetic identification obtained from BLAST was confirmed from phylogenetic analysis (Fig. 2), since the sequences obtained in this study clustered - without exceptions - together with reference sequences of the putative species, exhibiting a high bootstrapping support in all the cases. In Fig. 2 it can be seen that the reference sequences from different locations are interspersed in the clusters with the sequences obtained in this study, especially for Xenostrobus securis (with references from the neighbouring Galician waters and from Australia) and Watersipora subtorquata (references from Europe, America and Australia). 
Table 1

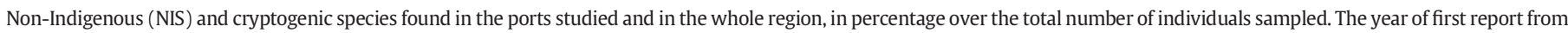

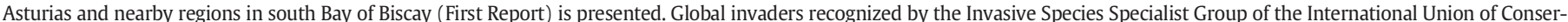

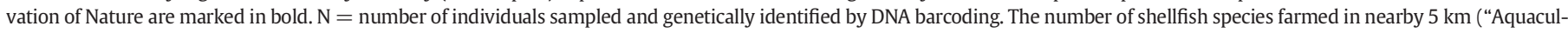
ture") and the total percent of NIS (\%NIS) are presented. Species names currently recognized by WoRMS.

\begin{tabular}{|c|c|c|c|c|c|c|c|c|c|c|}
\hline & First Report & Figueras & Luarca & Cudillero & Avilés & Gijón & Villaviciosa & Ribadesella & Llanes & Region \\
\hline Amathia verticillata & This study & 0.0 & 0.0 & 0.0 & 0.0 & 7.1 & 0.0 & 0.0 & 0.0 & 1.04 \\
\hline Amphibalanus amphitrite & This study & 0.0 & 0.0 & 0.0 & 4.1 & 0.0 & 1.0 & 0.0 & 0.0 & 0.74 \\
\hline Amphibalanus eburneus & This study & 0.0 & 0.0 & 0.0 & 4.1 & 0.0 & 0.0 & 0.0 & 0.0 & 0.56 \\
\hline Austrominius modestus & This study & 0.0 & 5.1 & 0.0 & 1.0 & 0.0 & 2.0 & 10.7 & 0.0 & 2.23 \\
\hline Botrylloides violaceus & 2009 (AquaNIS) & 5.6 & 0.0 & 0.0 & 0.0 & 0.0 & 0.0 & 0.0 & 0.0 & 0.6 \\
\hline Bugula neritina & 2003 (AquaNIS) & 1.4 & 0.0 & 0.0 & 0.0 & 0.0 & 4.0 & 0.0 & 1.0 & 0.89 \\
\hline Callyspongia siphonella & This study & 0.0 & 0.0 & 0.0 & 0.0 & 0.0 & 1.0 & 0.0 & 0.0 & 0.15 \\
\hline Crassostrea gigas & 1976 (Arias et al., 2012) & 1.4 & 0.0 & 0.0 & 0.0 & 0.0 & 6.0 & 40.5 & 4.0 & 6.7 \\
\hline Crepidula fornicata & 1978 (Arias et al., 2012) & 1.4 & 0.0 & 0.0 & 0.0 & 0.0 & 0.0 & 0.0 & 0.0 & 0.15 \\
\hline Ficopomatus enigmaticus & 2000 (AquaNIS, 2015) & 0.0 & 0.0 & 0.0 & 0.0 & 0.0 & 0.0 & 21.4 & 36.4 & 8.04 \\
\hline Livoneca redmanii & This study & 0.0 & 0.0 & 0.0 & 0.0 & 5.1 & 0.0 & 0.0 & 0.0 & 0.74 \\
\hline Microcosmus squamiger & 2007 (AquaNIS, 2015) & 0.0 & 0.0 & 0.0 & 0.0 & 1.0 & 2.0 & 0.0 & 1.0 & 0.6 \\
\hline Mytilaster minimus & 2014 (Pejovic et al., 2016) & & & & & & & & & \\
\hline Mytilus trossulus & This study & 2.8 & 3.4 & 1.6 & 0.0 & 4.0 & 2.0 & 0.0 & 2.0 & 1.93 \\
\hline Ostrea stentina & 2014 (Pejovic et al., 2016) & 0.0 & 0.0 & 0.0 & 0.0 & 0.0 & 1.0 & 0.0 & 0.0 & 0.15 \\
\hline Polydora triglanda & This study & 0.0 & 0.0 & 0.0 & 0.0 & 0.0 & 0.0 & 0.0 & 1.0 & 0.15 \\
\hline Styela clava & 2005 (AquaNIS, 2015) & 0.0 & 1.7 & 0.0 & 0.0 & 0.0 & 0.0 & 0.0 & 0.0 & 0.15 \\
\hline Styela plicata & 2009 (AquaNIS, 2015) & 0.0 & 0.0 & 0.0 & 0.0 & 3.0 & 0.0 & 0.0 & 0.0 & 0.45 \\
\hline Watersipora subtorquata & 2010 (AquaNIS, 2015) & 9.86 & 0 & 1.61 & 0 & 3.03 & 0 & 0 & 0 & 1.64 \\
\hline \multirow[t]{4}{*}{ Xenostrobus securis } & 2014 (Pejovic et al., 2016) & 0 & 0 & 0 & 54.64 & 0 & 0 & 0 & 0 & 7.89 \\
\hline & $\mathrm{N}$ & 71 & 59 & 62 & 97 & 99 & 100 & 84 & 99 & 671 \\
\hline & Aquaculture & C. gigas & 0 & 0 & 0 & 0 & Clams & C. gigas & 0 & \\
\hline & $\%$ NIS & 22.5 & 10.1 & 3.3 & 63.9 & 34.3 & 8.9 & 72.6 & 45.5 & \\
\hline
\end{tabular}

3.2. Diversity of native and non-indigenous species in the sampled assemblages

More abundant NIS in the region (Table 1 ) were $F$. enigmaticus (a tubeworm native to Oceania, 8.04\%), X. securis (black pygmy mussel, 7.9\%), C. gigas (Pacific oyster, 6.7\%) and Austrominius modestus (barnacle, $2.23 \%$ ). Overall, the proportion of detected NIS and cryptogenic species in the two national ports was significantly higher than in the six regional ones (Chi-square $=8.79, P<0.01$ ). The structural composition of the sampled assemblages varied from port to port (Fig. 3A). As evidenced from the nMDS plot and confirmed by SIMPER analysis, the samples from the two national ports were more similar to each other (average similarity 32.11 versus 22.45 for the regional ports). Largely,

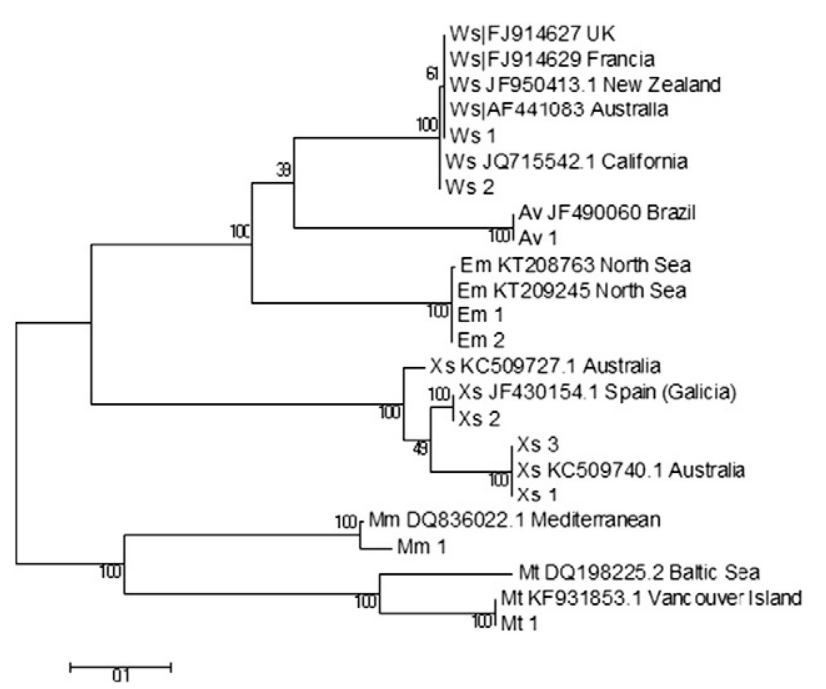

Fig. 2. Maximum-likelihood tree constructed from COI haplotypes of this study and GenBank references with voucher specimen. The geographical origin of the references is given. Av, Em, Mm, Mt., Ws and Xs are Amathia verticillata, Elminius modestus (former name of currently accepted Austrominius modestus; GenBank references have that name), Mytilaster minimus, Mytilus trossulus, Watersipora subtorquata and Xenostrobus securis, respectively.
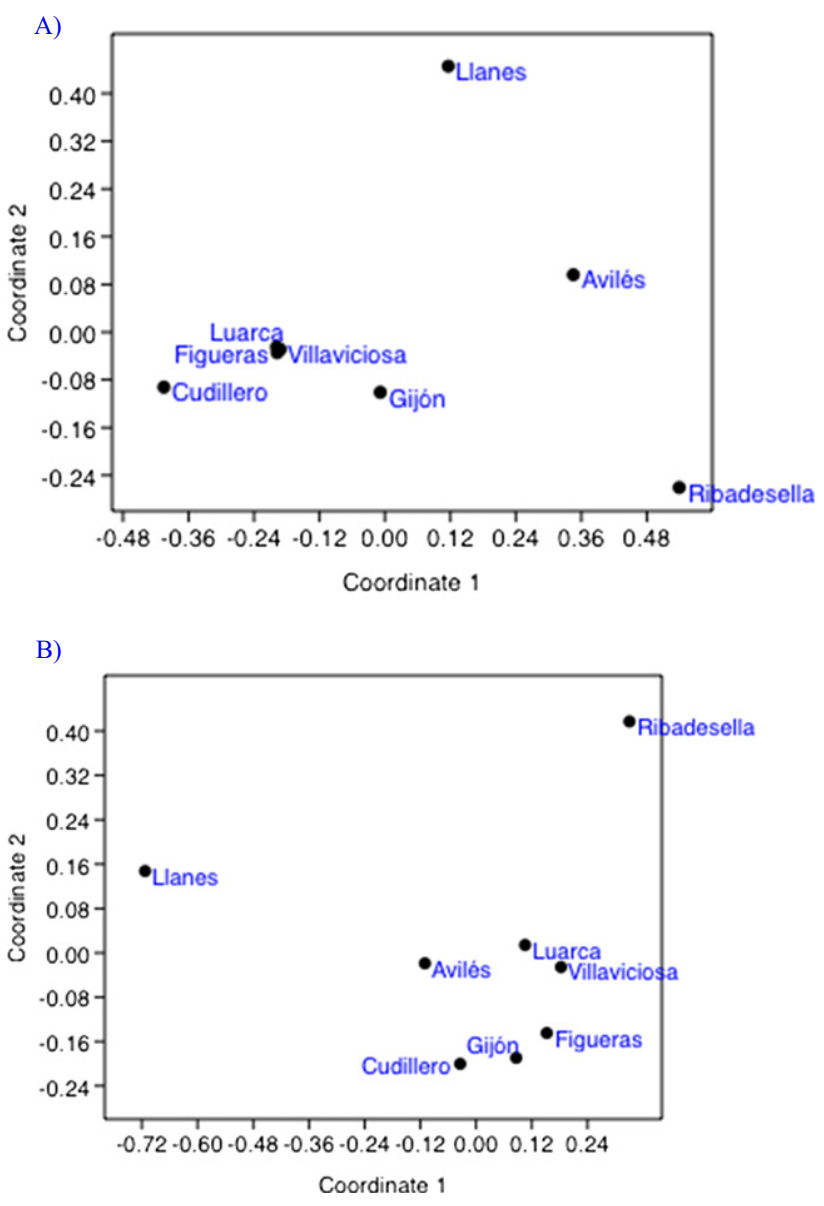

Fig. 3. Two-dimension plot created from non-metric multidimensional scaling based on Bray-Curtis similarity matrix of species counts, representing the eight ports analyzed. A: all species; B: only native species. 


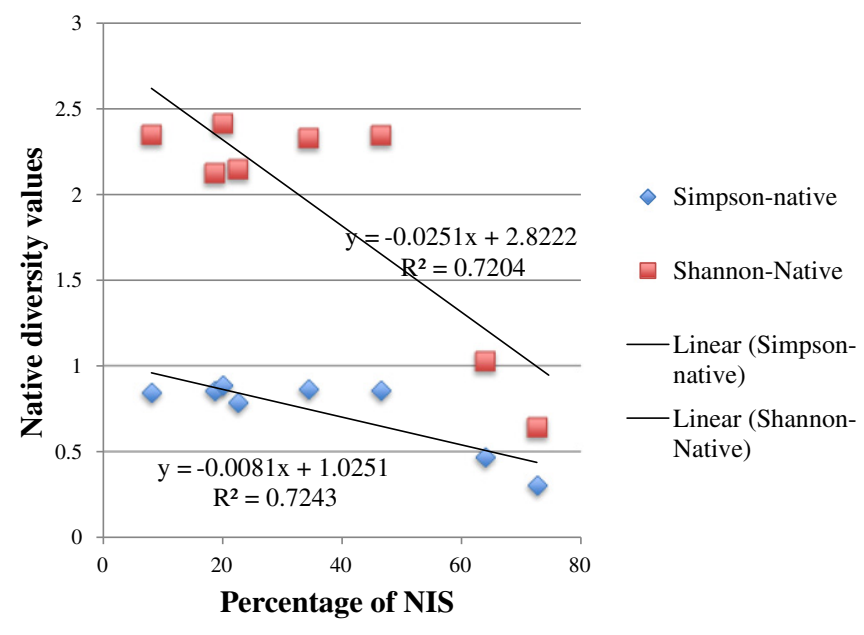

Fig. 4. Correlation between native diversity and proportion of NIS in the eight ports considered. Equation of the regression slopes and their $\mathrm{r}^{2}$ values are displayed on the plot.

such grouping was caused by the prevalence of $X$. securis in all samples from Aviles (69.85\% contribution to the within-port similarity).

Dominant natives (Supplementary Table 1) were molluscs, with 308 counts ( $74 \%$ of native individuals). The composition of native assemblages also varied among ports (Fig. 3B) that were arranged in a very different way in the nMDS compared with total biota (Fig. 3A). Native biodiversity measured from either Shannon or Simpson indices, significantly and negatively correlated with NIS proportion in the eight ports studied (Fig. 4). Tests gave $r=-0.851, P=0.007$ and $r=0.849$, $P=0.008$ for correlations between the proportion of NIS individuals and Simpson's and Shannon's indices respectively. The total number of native species per se, however, was not significantly correlated with \%NIS at the significance level employed here $(r=-0.793, P=0.019>0.016)$.

\section{Discussion}

In this study we reported high proportion of NIS and cryptogenic species, as much as $38 \%$, from North Iberian ports. The presence of $A$. modestus in the Bay of Biscay was detected for the first time and we have provided 671 new barcodes for marine macrofauna. For the species with phenotypic plasticity, high bootstrapping support of barcode clustering with references from different locations suggests that multiple introductions have occurred in the region. Some of them were from very distant regions such as Australia, New Zealand, California, Vancouver. However this should be taken with caution because the phylogeographic signal is generally weak in widespread marine invaders. Organisms attached to hulls or transported in ballast water may go back and forth following the complex itineraries of the carrier ships. In a very short time their propagules may be released in intermediate locations. Eventually they can get transported further either via the same shipping vectors or other means (including natural spread), adopting the 'stepping-stones' model of range expansion (e.g. Apte et al., 2000; Floerl et al., 2009). On the other hand, for some species morphologically identified we have found $<97 \%$ nucleotide identity with databases references of that species. This could be due to intra-specific variation, and the lack of a good geographical coverage of reference barcodes in databases.

The detected NIS were not homogeneously distributed in the eight ports studied; instead, they negatively correlated with native biodiversity present in the same locations. Biotic communities attached to artificial structures in ports are different from surrounding areas (e.g. Glasby, 1999; Bax et al., 2003), thus it is a novelty - and probably good news - to find the same type of biotic resistance that happens in more natural marine settings. At a smaller spatial scale $\left(100 \mathrm{~cm}^{2}\right)$, survival of exotic species was inversely correlated with native species richness in experimental communities of marine sessile invertebrates, probably due to reduced available space that was the limiting resource there (Stachowicz et al., 1999). Space was probably not limiting in our study since the artificial structures examined were not completely covered by biota in any case. Byers and Noonburg (2003) suggested that the invasibility of communities decreases with increasing native diversity because the sum of interactions between native and exotic species increases in turn, not only due to scarcer available resources. This could be a plausible explanation in the ports studied here, where many native species were present: between 6 and 19 (Supplementary Table 1), compared with 1 to 4 native species in Stachowicz et al.' (1999) experiments. In an extensive review, Fridley et al. (2007) concluded that reduction of local species richness accelerates the invasion in natively rich ecosystems. Periodic cleaning of artificial structures could have an effect in ports' invasion patterns, but in absence of previous biodiversity inventories we cannot know if this explanation can be applied in our specific case study.

Human economic and demographic factors are major predictors of biological invasions (Pysec et al., 2010), and accordingly in this study we found significant differences between the two ports located in bigger urban locations (Aviles and Gijon) versus regional ports located in villages. To exclude a bias due to mixing ports of different size and surrounding human influence in the same analysis, we did again the correlation only for the six regional ports and Simpson diversity (the best indicator for our dataset). In this partial dataset it was also negatively and significantly correlated with the proportion of NIS ( $r=-0.832$, $P=0.039$ ), suggesting that the biotic resistance in ports is a phenomenon that occurs at different scales. In the same direction, spread of NIS from international ports in a region by local maritime traffic was expected (e.g. Wasson et al., 2001). In the present study, however, the regional ports located in the vicinity of the two international ports did not contain a higher proportion of NIS than other regional ports (Table 1). Thus NIS proportion was not associated with the distance to the international ports. It is possible that the biotic resistance may compensate the expected higher NIS flow near international ports.

Although our sampling was restricted to fouling communities from ports, the level of taxonomic diversity found did not differ much from previous biota inventories carried out in this coast (e.g. Louzao et al., 2010). In benthos they found approximately 75 species in average from two coastal locations, which is roughly comparable to our $>70$ species found with a much lower sampling effort (exhaustive sampling in Louza et al., 2010 versus approximately 1/100 individuals sampled in our study). This is also an indirect indication of the high species richness, and not only NIS, that can be supported inside the ports.

As a final remark, the results of this study suggest native biota confers some protection against biological invasions in maritime ports. Since these are hubs for invaders (Floerl et al., 2009), they should be priority targets for control actions. Perhaps enhancing native biota inside the ports - or simply not removing it completely, as it is commonly done today - would help biotic resistance to prevent NIS from settling. Exploring this possibility may be encouraged, at least at experimental level in small ports. If successful it might be considered as one more strategy for controlling aquatic invasions.

Supplementary data to this article can be found online at http://dx. doi.org/10.1016/j.marpolbul.2016.08.022.

\section{Acknowledgments}

This study has been funded by the Spanish Ministry of Economy and Competitiveness, Grant CGL-2013-42415-R and the Principality of Asturias (Spain), Grant GRUPIN-2014-093. This is a contribution from the Marine Observatory of Asturias (OMA). Alba Ardura is recipient of a Postdoctoral Fellowship with reference Clarin-COFUND-PCTI-FICYT. Laura Clusa holds a PCTI Grant from the Asturias Regional Government, referenced BP14-145. We are grateful to an anonymous Reviewer who kindly helped to improve this manuscript. 


\section{References}

Apte, S., Holland, B.S., Godwin, L.S., Gardner, J.P.A., 2000. Jumping ship: a stepping stone event mediating transfer of a non-indigenous species via a potentially unsuitable environment. Biol. Invasions 2, 75-79.

AquaNIS. Editorial Board, 2015. Information System on Aquatic Non-Indigenous and Cryptogenic Species. World Wide Web electronic publication (www.corpi.ku.lt/ databases/aquanis. Version 2.36+. Accessed 2016-08-06).

Ardura, A., Planes, S., Garcia-Vazquez, E., 2015. Aliens in paradise. Boat density and exotic coastal mollusks in Moorea Island (French Polynesia). Mar. Environ. Res. 112, 56-63.

Arias, A., Anadón, N., 2012. First record of Mercenaria mercenaria (Bivalvia: Veneridae) and Ensis directus (Bivalvia: Pharidae) on bay of Biscay, Iberian peninsula. J. Shellfish Res. 31, 57-60.

Arias, A., Richter, A., Anadón, N., 2012. Estado actual de los Moluscos marinos no autóctonos en aguas del Cantábrico. In: GEIB Grupo Especialista en Invasiones Biológicas (Ed.), EEI 2012 Notas Científicas. $4^{\circ}$ Congreso Nacional sobre Especies Exóticas Invasoras “EEI 2012”. GEIB, Serie Técnica N 5, pp. 99-103 (León, Spain. (in Spanish)).

Bax, N., Williamson, A., Aguero, M., Gonzalez, E., Geeves, W., 2003. Marine invasive alien species: a threat to global biodiversity. Mar. Policy 27, 313-323.

Byers, J.E., Noonburg, E.G., 2003. Scale dependent effects of biotic resistance to biological invasion. Ecology 84, 1428-1433.

Clarke, K.R., 1993. Non-parametric multivariate analyses of changes in community structure. Aust. J. Ecol. 18, 117-143.

Devloo-Delva, F., Miralles, L., Ardura, A., Borrell, Y.J., Pejovic, I., Tsartsianidou, V., GarciaVazquez, E., 2016. Detection and characterisation of the biopollutant Xenostrobus securis (Lamarck 1819) Asturian population from DNA barcoding and eBarcoding. Mar. Pollut. Bull. 105, 23-29.

Distel, D.L., Amin, M., Burgoyne, A., Linton, E., Mamangkey, G., Morrill, W., et al., 2011. Molecular phylogeny of Pholadoidea Lamarck, 1809 supports a single origin for xylotrophy (wood feeding) and xylotrophic bacterial endosymbiosis in Bivalvia. Mol. Phylogenet. Evol. 61 (2), 245-254.

Estoup, A., Largiader, C.R., Perrot, E., Chourrout, D., 1996. Rapid one-tube DNA extraction protocol for reliable PCR detection of fish polymorphic markers and transgenes. Mol. Mar. Biol. Biotechnol. 5 (4), 295-298.

Fabioux, C., Huvet, A., Lapègue, S., Heurtebise, S., Boudry, P., 2002. Past and present geographical distribution of populations of Portuguese (Crassostrea angulata) and Pacific (C. gigas) oysters along the European and north African Atlantic coasts. Haliotis 31, 33-44.

Floerl, O., Inglis, G.J., Dey, K., Smith, A., 2009. The importance of transport hubs in stepping-stone invasions. J. Appl. Ecol. 46, 37-45.

Fridley, J.D., Stachowicz, J.J., Naeem, S., Sax, D.F., Seabloom, E.W., Smith, M.D., Stohlgren, T.J., Tilman, D., Holle, B.V., 2007. The invasion paradox: reconciling pattern and process in species invasions. Ecology 88, 3-17.

Geller, J., Meyer, C., Parker, M., Hawk, H., 2013. Redesign of PCR primers for mitochondrial cytochrome c oxidase subunit I for marine invertebrates and application in all-taxa biotic surveys. Mol. Ecol. Resour. 13 (5), 851-861.

Glasby, T.M., 1999. Differences between subtidal epibiota on pier pilings and rocky reefs at marinas in Sydney, Australia. Estuar. Coast. Shelf Sci. 48, 281-290.

Habtemariam, B.T., Arias, A., García-Vázquez, E., Borrell, Y.J., 2015. Impacts of supplementation aquaculture on the genetic diversity of wild Ruditapes decussatus from northern Spain. Aquacult. Env. Interac. 6 (3), 241.

Hall, T.A., 1999. BioEdit: a user-friendly biological sequence alignment editor and analysis program for Windows 95/98/NT. Nucleic Acids Symp. Ser. 41, 95-98.

Hopkins, G.A., Forrest, B.M., Jiang, W., Gardner, J.P.A., 2011. Successful eradication of a non-indigenous marine bivalve from a subtidal soft sediment environment. J. Appl. Ecol. 48, 424-431.

Librado, P., Rozas, J., 2009. DnaSP v5: a software for comprehensive analysis of DNA polymorphism data. Bioinformatics 25, 1451-1452.

Linde, A.R., Izquierdo, J.I., Moreira, J., Garcia-Vazquez, E., 2008. Invasive tilapia juveniles are associated with degraded river habitats. Aquat. Conserv. 18 (6), 891-895.

Louzao, M., Anadón, N., Arrontes, J., Álvarez-Claudio, C., Fuente, D.M., Ocharan, F., Anadón, A., Acuña, J.L., 2010. Historical macrobenthic community assemblages in the Avilés Canyon, N Iberian shelf: baseline biodiversity information for a marine protected area. J. Mar. Syst. 80, 47-56.
MacDougall, A.S., Turkington, R., 2005. Are invasive species the drivers or passengers of change in degraded ecosystems? Ecology 86, 42-55.

Mackie, J.A., Darling, J.A., Geller, J.B., 2012. Ecology of cryptic invasions: latitudinal segregation among Watersipora (Bryozoa) species. Sci. Rep. 2 (871), 1-10.

Minchin, D., 2007. Rapid coastal survey for targeted alien species associated with floating pontoons in Ireland. Aquat. Invasions 2 (1), 63-70.

Miralles, L., Dopico, E., Devloo-Delva, F., Garcia-Vazquez, E., 2016. Controlling populations of invasive pygmy mussel (Xenostrobus securis) through citizen science and environmental DNA. Mar. Pollut. Bull. 110 (1), 127-132.

Molnar, J.L., Gamboa, R.L., Revenga, C., Spalding, M.D., 2008. Assessing the global threat of invasive species to marine biodiversity. Front. Ecol. Environ. 6, 485-492.

Myers, J.H., Simberloff, D., Kuris, A.M., Carey, J.R., 2000. Eradication revisited: dealing with exotic species. Trends Ecol. Evol. 15, 316-320.

Pejovic, I., Ardura, A., Miralles, L., Arias, A., Borrell, Y.J., Garcia-Vazquez, E., 2016. DNA barcoding for assessment of exotic molluscs associated with maritime ports in northern Iberia. Mar. Biol. Res. 12 (2), 168-176.

Pochon, X., Zaiko, A., Hopkins, G.A., Banks, J.C., Wood, S.A., 2015. Early detection of eukaryotic communities from marine biofilm using high-throughput sequencing: an assessment of different sampling devices. Biofouling 31 (3), 241-251.

Pysec, P., Jarošík, V., Hulme, P.E., Kühn, I., Wild, J., Arianoutsou, M., Bacher, S., Chiron, F., Didžiulis, V., Essl, F., Genovesi, P., Gherardi, F., Hejda, M., Kark, S., Lambdon, P.W. Desprez-Loustau, M.-L., Nentwig, W., Pergl, J., Poboljšaj, K., Rabitsch, W., Roques, A Roy, D.B., Shirley, S., Solarz, W., Vilà, M., Winter, M., 2010. Disentangling the role of environmental and human pressures on biological invasions across Europe. Proc. Natl. Acad. Sci. U. S. A. 107, 12157-12162.

R Development Core Team, 2014. R: A Language and Environment for Statistical Computing. R Foundation for Statistical Computing, Vienna, Austria (http://www.R-project. org/).

Seebens, H., Gastner, M.T., Blasius, B., 2013. The risk of marine bioinvasion caused by global shipping. Ecol. Lett. 16 (6), 782-790.

Semeraro, A., Mohammed-Geba, K., Arias, A., Anadón, N., Garcia-Vazquez, E., Borrell, Y.J., 2015. Genetic diversity and connectivity patterns of harvested and aquacultured molluscs in estuaries from Asturias (northern Spain). Implications for management strategies. Aquac. Res. http://dx.doi.org/10.1111/are.12745.

Stachowicz, J.J., Whitlatch, R.B., Osman, R.W., 1999. Species diversity and invasion resistance in a marine ecosystem. Science 286, 1577-1579.

Tamura, K., Nei, M., 1993. Estimation of the number of nucleotide substitutions in the control region of mitochondrial DNA in humans and chimpanzes. Mol. Biol. Evol. 10 512-526.

Tamura, K., Stecher, G., Peterson, D., Filipski, A., Kumar, S., 2013. MEGA6: molecular evolutionary genetics analysis version 6.0. Mol. Biol. Evol. 30, 2725-2729.

Thompson, J.D., Higgins, D.G., Gibson, T.J., 1994. CLUSTAL W: improving the sensitivity of progressive multiple sequence alignment through sequence weighting, position-specific gap penalties and weight matrix choice. Nucleic Acids Res. 22, 4673-4680.

Thresher, R.E., Kuris, A.M., 2004. Options for managing invasive marine species. Biol. Invasions 6 (3), 295-300.

Valiente, A.G., Juanes, F., Nuñez, P., Garcia-Vazquez, E., 2010a. Brown trout (Salmo trutta) invasiveness: plasticity in life-history is more important than genetic variability. Biol. Invasions 12, 451-462.

Valiente, A.G., Ayllon, F., Nuñez, P., Juanes, F., Garcia-Vazquez, E., 2010b. Not all lineages are equally invasive: genetic origin and life-history in Atlantic salmon and brown trout acclimated to the southern hemisphere. Biol. Invasions 12, 3485-3495.

Wasson, K., Zabin, C.J., Bedinger, L., Diaz, M.C., Pearse, J.S., 2001. Biological invasions of estuaries without international shipping: the importance of intraregional transport. Biol. Conserv. 102 (2), 143-153.

Williams, S.L., Schroeder, S.L., 2004. Eradication of the invasive seaweed Caulerpa taxifolia by chlorine bleach. Mar. Ecol. Prog. Ser. 272, 69-76.

WoRMS Editorial Board World, 2016. Register of marine species. Available from http:// www.marinespecies.org (at VLIZ. Accessed 2016-06-26).

Zaiko, A., Olenin, S., Daunys, D., Nalepa, T., 2007. Vulnerability of benthic habitats to the aquatic invasive species. Biol. Invasions 9, 703-714.

Zaiko, A., Lehtiniemi, M., Narščius, A., Olenin, S., 2011. Assessment of bioinvasion impacts on a regional scale: a comparative approach. Biol. Invasions 13, 1739-1765. 